\title{
Community Development, Peace and Canadian Bilateral Aid in El Salvador
}

\author{
Lisa Kowalchuk and Liisa L. North ${ }^{1}$
}

Is Canadian development assistance building peace in El Salvador? The Canadian International Development Agency's (CIDA's) current aid program was certainly designed to support the country's ambitious peace process, inaugurated by the signing of the Chapultepec Accords in January 1992. Those accords, in turn, were intended not only to end El Salvador's twelve-year civil war but also to eradicate its causes.

It is generally agreed that the civil war derived from a development model that denied the majority of the population access to the minimum resources required to satisfy basic human needs and a political system that repressed all peaceful efforts to bring about social justice. Consequently, in addition to essential reforms intended to reduce the size of military and security forces and bring them under civilian control, the Chapultepec Accords included a broad range of reforms to civilian institutions: in the political realm, electoral and judicial systems, and in the socioeconomic realm, land tenure and labour-capital relations.

To what extent had the accords been implemented as of the fall of 1993? Ironically, despite the many problems encountered in the implementation of the military-security clauses, many observers of the peace process were convinced that "it will be easier to overcome the structural problems in the military than those in the judicial system" (LCHR 1993, 4) and the civilian arena in general. Such reforms, after all, challenge the traditional structures of political power and socioeconomic privilege in the country. Despite the supervision and en-

Lisa Kowalchuk is a doctoral candidate in the Department of Sociology, and Liisa L. North is a professor in the Department of Political Science at York University. couragement of the United Nations Observer Mission in El Salvador (ONUSAL), implementation has turned out to be difficult and uneven.

Perhaps most ominously, rightist death squads have begun to function again. In the fall of 1993, church officials reported an average of twelve death squad style killings per month while ONUSAL stated that it viewed the peace process "with deep concern" since "serious violations have become more acute." (The Globe and Mail 23 October 1993, A14). Thus, while many people were returning to El Salvador after years of exile, others continued to leave, seeking external refuge.

It is within this context that CIDA's program in El Salvador must be analyzed. Following a brief description of our criteria for evaluating what may be considered peace building assistance, we will turn to the community development part of the Canadian program. Concluding remarks will deal with the poor fit between economic structural adjustment policies and peace building.

\section{The Criteria for Evaluating Peace Building Assistance}

Eight interrelated criteria derived from the work of Canada-CaribbeanCentral America Policy Alternatives (CAPA) guide our assessment of Canada's contribution to peace in El Salvador. These criteria are consistent with the text of the peace accords ${ }^{2}$ as well as the analyses of the contributors to Robert Miller's Aid as Peace-Maker. To promote peace, David Close argues, development assistance must "undermine the structures that created the original conflict" (Close 1992, 31; North 1990). In specific terms, to promote peace, we propose that international assistance must:

1. help countervail the power of entrenched civilian and military elites by supporting those social forces that are promoting long term peace;

2. support the reduction of socioeconomic inequalities;

3. promote the political participation of marginalized groups, especially women;

4. be formulated in consultation with local organizations with relevant knowledge and experience;

5. rely on the participation of recipients in defining and executing the projects financed;

6. promote the reconciliation of historical antagonists;

7. decrease-or at least not deependependency on technologies and production inputs that have to be imported; and

8. foster environmental sustainability.

The Canadian Assistance Program

Following the January 1992 Accords, Canada created a $\$ 5$ million "interim" development assistance fund for $\mathrm{El}$ Salvador. That fund, a "bridge" to a new five year program scheduled to begin this year, had two main components: \$2.6 million for "democratic development and human rights," designated for government institutions created by the peace accords and nongovernmental organizations that worked to ensure a genuine implementation of the accords; and \$2.3 million for new kinds of community development projects.

The latter, our focus here, was added to the existing "Programme of Support for Community Development" (PADECO) administered by the Canadian Hunger Foundation (CHF). ${ }^{3}$ For the most part, it financed projects in the former conflict zones: communities of repatriates, the internally displaced, ex-combatants of the rebel organizations, and economically marginalized people. Lisa Kowalchuk visited five of the twenty PADECO 
projects during the summer of 1993 and our analysis is confined to them.

Nueva Esperanza and Ciudad Romero, both located in the western department of Usulután, are communities in which PADECO provided support for repatriated refugees attempting to rebuild a livelihood destroyed by the civil war. Two and a half hours from the capital city, the last 45 minutes of which are negotiable only in a four-wheel drive vehicle, Nueva Esperanza is a small community founded by some three hundred refugees who repatriated from Nicaragua where they had been since the early 1980 s. The $\$ 226,000$ delivered by the CHF financed house construction, the purchase of dairy cattle, and the planting of fruit and other trees. The housing project consisted of 54 identical modest, four room, cement-bricked buildings constructed with locally available materials. The collectively owned and locally available livestock purchased with the Canadian funds were expected to reproduce themselves. Milk production, still at a modest level in the summer of 1993 , served the community's own consumption needs, but eventually the sale of surplus milk and beef was planned. Limes, plantains, oranges and other fruit had been planted and it was anticipated that the trees, though intended to produce mainly for community consumption, would yield a marketable surplus within a couple of years.

About half a kilometre from Nueva Esperanza, Ciudad Romero is a community of almost nine hundred people, most of whom repatriated from Panama. Its $\$ 200,000$ donation was used solely for housing. Indicative of the CHF's flexibility, the initially designated amount was doubled when more people than anticipated arrived in the community. While this project does not contribute to income generation (as the project in Nueva Esperanza does), it is responding to an essential component of the reintegration of returning refugees.

In the communities of San Jerónimo and Sisiguaya, in the departments of
San Vicente and Usulután respectively, PADECO supports income generating activities for cooperatives of former FMLN combatants. A CHF-administered donation of $\$ 96,423$ has purchased beef and dairy cattle in San Jerónimo. A donation of $\$ 98,340$ to a thirty-five member cooperative of excombatants-the " 31 Diciembre" - financed the commercialization of salt in Sisiguaya, benefitting 210 persons. The funds purchased a warehouse to store the salt and equipment to grind and iodize it. Part of the donation was earmarked to contract the services of the Institute of Technology, Self-Management and Environment (ITAMA) for technical training and a study of the environmental impact of the salt production enterprise. Like the project in Nueva Esperanza, these projects also helped to redress the economic marginalization of sectors of society that emerged from the civil war with few options for economic self-sufficiency.

In all three of these cases, PADECO was supporting existing cooperative responses to employment creation, income generation or the housing deficit. Another project, the Cooperative Services Central, designated funds to promote cooperativism as an alternative among individual small scale producers. This project involved training in the management of cooperative financing, marketing and input purchases for agricultural production among 170 beneficiaries in five neighbouring communities in the department of Cabañas. The communities varied in their levels of prosperity, with Bañadero (the poorest, with high levels of illiteracy) at one extreme and Rojas (with many brick houses, including some with trucks in their driveways) at the other.

The $\$ 98,000$ provided to the Cooperative Services Central by PADECO served as "seed capital" - a substitute for bank loans which, as individuals, the recipients had virtually no hope of obtaining - to finance the purchase of inputs and to clear land for cultivation. The recipients were encouraged to think of the funds as loans (rather than donations) for the cultivation of the individual plots that they either rented or, much more rarely, owned. In each community, cooperative members organized themselves into small groups of six or seven to supervise loan repayment. A small proportion of the donation was earmarked to pay the expenses of consultants from the Salvadorean Institute of Cooperative Education and Consulting Services (ISEAC). They gave seminars to the coop members in loan management and made weekly supervisory visits to each community.

\section{Evaluation}

Overall, the CHF program lived up to its billing as a genuine community development program, and it satisfies most of our criteria for peace building development. Cooperatives respond to the problems faced by El Salvador's majority of underemployed, an $\mathrm{I}$ small producers represent a significant proportion of the program's beneficiaries. At a recent conference on cooperativism and human rights, it was pointed out that the country's fifteen hundred existing cooperatives have come to generate some 25 percent of national income, and have the additional advantage of being labour-intensive (Diario Latino 17 August 1993, 24). Environmental considerations were being taken into account in the $\mathrm{CHF}$ projects, with appropriate technologies introduced and training provided. In addition, the utilization of local rather than imported production inputs in the projects conserves economic multiplier effects for domestic benefit. Furthermore, the CHF's declared emphasis on the full participation of recipients in devising and implementing their projects was evident in practice. This not only promotes the self-sustainability of the projects but also ensures that they address the real needs of the beneficiaries. Finally, by giving priority to communities in the former conflict zones, the PADECO program contributed to the productive reintegration of ex-combatants and refugees upon which post-conflict reconciliation depends. 
However, a serious shortcoming of the PADECO program arises from the CHF's failure to fully consult with or to fund the local umbrella organizations to which many of the recipient communities belong. The CHF's policy of avoiding local nongovernmental organizations (NGOs) almost entirely is intended to promote the recipients' capacity to manage their own affairs. The $\mathrm{CHF}$ also argues that funds often tend to get caught up in the bureaucracies of the NGOs or face delays in delivery due to project saturation. ${ }^{5}$

As legitimate as these reasons may be, by-passing the local NGOs as a general policy is counter-productive. Many of the recipient communities rely on those NGOs and are consequently less likely to reach self-sustainability without their continued support. To provide that support, the NGOs also require funding. It costs money to pay agronomists and community development experts who can, for example, promote women's participation and literacy or train the bookkeepers and treasurers of new cooperatives.

Nor is funding the only issue. Equally problematic is the CHF's insufficient consultation with the Salvadorean NGOs who have a history of working with marginalized groups. This may diminish the developmental impact of projects at both the community and regional levels. For example, a member of ITAMA finds the intervention of foreign donors in this community disruptive of its internal social relations. The "31 Diciembre" cooperative of ex-combatants was assigned control of the salt production facilities, as a condition for receiving support from the European Economic Community. However, according to the ITAMA critic, the salt works used to be "the lifeblood" of the civilians in Sisiguaya. With foreign funding designated only for ex-combatants, civilians and their cooperatives could be left without assistance, a situation which could possible lead to the emergence of greater inequality and the disruption of the community's development. ${ }^{6}$ Moreover, local NGOs could have assisted in ensuring that women -now conspicuously absent among the participants-benefitted from the project. Had the CHF consulted more carefully with ITAMA on possible alternatives, the Canadian agency would have been introduced to their argument for greater coordination among the several cooperatives in the community. Commenting on a similar dilemma, a researcher employed by the "Fundación 16 Enero" to develop reintegration programs for ex-combatants, suggested community banks for the receipt of foreign donations so that former combatants would be treated as integral members of the community and not as a privileged sect.

The CHF policy also leads to lost opportunities: its projects are not articulated within the broader visions of regional development toward which many of the Salvadorean organizations are working. For example, PADECO funded recipients Neuva Esperanza and Lempa Mar are members of the Cooperative and Community Coordination for the Integral Development of the Coast (CODECOSTA), an association of communities that promotes the "integral development" of some twenty communities and cooperatives in Usulután. CODECOSTA has coordinated joint efforts to construct and use infrastructure for health care and education; encouraged the sharing of machinery and ideas; and developed a dairy project in which several communities in the zone participate. ${ }^{7}$ Yet, CODECOSTA has not been supported or consulted by the CHF.

Clearly, the perspectives of CODECOSTA and similar NGOs on regional development should be taken into account by foreign donors. As a consultant to the Jesuit Development Service explained, the coordination of production, consumption and marketing among communities can avoid the duplication of efforts, and can maximize and share the advantages that some areas might have with respect to topography, irrigation and the like. ${ }^{8}$

The CHF's political rationale for avoiding local NGOs also has to be examined. The Foundation asserts that direct funding circumvents accusations by the Salvadorean government that it supports the left. ${ }^{9}$ But if international donors do not support El Salvador's beleaguered progressive forces, the peace process is imperiled. The message of democratic inclusion must be reiterated to the recalcitrant sectors of the country's elite which have recently reactivated the death squads that killed thousands of labour, peasant and cooperative leaders in the 1980s. Mario López, the founding director of ITAMA and the Vice-President of its Board of Directors, was assassinated on December 9, 1993. Mr. López was only one of several FMLN leaders and candidates for political office to be assassinated in the fall of 1993.

\section{Structural Adjustment Conditionality}

Canadian development assistance is conditioned on the adoption of structural adjustment policies by recipient countries. These typically involve the reduction of state subsidies to productive sectors, cutbacks in social programs such as education and health, the privatization of public enterprises, and the liberalization of trade, foreign investment and financial markets. In El Salvador, these policies are threatening to undermine the peace process, a fact that has not escaped the attention of the Secretary General of the United Nations and the former mediator of the Salvadorean peace negotiations (de Soto et al. 1993, para 95).

How may these policies contradict peace building projects? If credit programs to small farmers are slashed in the name of fiscal austerity, the potential development of the cooperative sector that CIDA has funded may be undercut. If the market is flooded with imported grains as a consequence of trade liberalization, displaced grain producers will easily outnumber the members of the fruit, cattle and dairy cooperatives supported by CIDA funds. If public education, including adult education is not made more accessible in the rural areas of El Salva- 
dor, the possibilities of democratization and development are prejudiced. If no concerted large scale programs are undertaken to provide employment to both rebel ex-combatants and demobilized soldiers of the Salvadorean armed forces, new waves of violence may destroy all efforts to construct a more democratic and economically viable society.

Moreover, the economic policies championed by international financial institutions and government donors favour precisely those elite groups that have resisted democratic reforms in the past and continue to resist the full implementation of the peace accords today. Their most recalcitrant members continued to finance death squads to eliminate their political opponents. ${ }^{10}$ The rich, who were getting richer with these policies, were already sending their children to private schools and to study abroad so they had no stake in improving the public education system upon which the future democratic development of the country depends. The privatization of banks has allowed rampant currency speculation. Income taxes were cutsupposedly to favour investmentwhile consumer taxes that hit the poor were increased. This, when by all accounts, more money in the hands of the wealthy favours luxury imports and capital export (Rosenberg 1992).

It needs to be stressed that the value of imports was more than twice the value of exports in 1992 and, significantly, the proportion of consumer durables in the import mix also doubled. A balance of payments crisis was avoided only due to the high level of emigrants' remittances. Remittances reached US\$718 million and represented 123 percent of exports in 1992, in contrast to 67 percent of exports in 1991 (Arriola 1992, 4). It was those remittances, rather than a reactivation of the national economy, that sustained the poorer sectors in particular. The sustainability of such as system is questionable since most observers expect remittance levels to decrease over time.

Overall, the macroeconomic and structural adjustment policies gener- ate results that contradict two of our criteria for peace building assistance: the power of entrenched elites is reinforced instead of curtailed; and social inequalities are increasing instead of being reduced. It should be stressed that the new inequalities generated by structural adjustment policies were appearing in the country with the most skewed income distribution profile in a region notorious for inequality. While El Salvador's rich wanted more, in 1990, 52 percent of the country's population was indigent and another 19 percent could not satisfy its basic needs (FLASCO 1992, 10). International funding will amount to little more than temporary "welfare relief" unless public policy favours the poor and the marginalized instead of imposing an austerity that the elites themselves do not practice.

The structural adjustment policies pursued in Nicaragua, after the Sandinistas lost the national elections of February 1990, were a primary cause of that country's descent into renewed armed conflict and refugee flight to neighbouring countries. We fear that El Salvador will follow in Nicaragua's sad footsteps unless the current opportunities for building peace are used to their full potential. That means creating an economic and social policy framework that favours democratization, socially viable development and the full complement of human rights...

\section{Notes}

1. The authors wish to thank the many individuals-too many to identify in this small space-in El Salvador and Canada who assisted our research. The support of the Social Sciences and Humanities Research Council Small Grants Programme and the York University Faculty of Arts Research Grant Programme made possible Lisa Kowalchuk's summer 1993 field work in El Salvador. This article is a shortened version of a longer work. "Canadian Assistance in El Salvador: A Contribution to Peace Building?" an Occasional Paper by Canada-Caribbean-Central America Policy Altermatives (CAPA). Toronto, 1993.

2. The text of all the peace agreements (there were several negotiated over two years) can be found in El Salvador Agreements: The Path to Peace. New York: United Na- tions Department of Public Information, July 1992.

3. For an analysis of the Democratic Development and Human Rights Fund, see the work from which this article is derived, as cited in footnote 1.

4. The names of institutions are translated into English but their Spanish acronyms are given.

5. Interview with CHF staff, San Salvador, 6 July 1993.

6. Interview with a member of ITAMA, San Salvador, 25 August 1993.

7. Interview with Armando Martinez, at the office of CODECOSTA, San Salvador, 27 August 1993.

8. Interview, San Salvador, 25 June 1993.

9. Interviews with CHF staff in San Salvador, 6 July 1993.

10. Their past involvement has been documented in the report of the Commission on the Truth and also in the documents recently released by the U.S. State Department, Defence Department, and Central Intelligence Agency under Congressional pressure (Krauss 1993, 4A).

\section{References}

Arriola, Joaquín. 1992. Coyuntura Económica de El Salvador 1992. Unpublished paper. San Salvador: Universidad Catolica Autonoma.

Close, David. 1992. “Aid as Peacemaker: Central America," In Robert Miller (ed.), Aid as Peacemaker: Canadian Development Assistance and Third World Conflict.

de Soto, Alvaro and del Castillo, Graciana. 1993. "An Integrated International Approach to Human Security. El Salvador: A Case Study." Report of the Secretary General, S/25812. Geneva. (May 21).

Facultad Latinoamericana de Ciencias Sociales (FLASCO). 1992. Perfil Estadistico Centroamericano. San José: FLACSO.

Krauss, Clifford. 1993. "U.S. Aware of Killings, Worked with Salvador's Rightists, Papers Suggest." In The New York Times, November 9.

Lawyers Committee for Human Rights/The Americas. 1993. El Salvador's Negotiated Revolution: Prospects for Legal Reform. New York (June).

Miller, Robert (ed.). 1992. Aid as Peacemaker: Canadian Development Assistance and Third World Conflict. Ottawa: Carleton University Press.

North, Liisa with CAPA (eds.). 1990. Between War and Peace in Central America: Choices for Canada. Toronto: Between The Lines Press.

Rosenberg. Tina. 1992. The Children of Cain: Violence and the Violent in Latin America. London: Penguin Books. $\square$ 